\title{
The Influence Of Health Education With A Think Pair Share Learning Model On The Knowledge And Attitudes Of School-Age Children In Vegetable Consumption
}

\author{
Sri Puasti Ningsih
}

Nursing Education Study Program, Faculty of Nursing Universitas Airlangga Surabaya

\section{ARTICLE INFO}

Keywords:

Knowledge, Attitudes, SchoolAge Children, Vegetable Consumption.
E-mail:

sripuasti08@gmail.com

\section{ABSTRACT}

The school-age group of children needs to get the fulfillment of the adequacy of its main nutrients with vegetable consumption. In fact, children still find it difficult to consume vegetables in adequate quantities. The think pair share method makes children will try to think, respond to each other and help in discussions. The aim of the study was to analyze the effect of the application of health education with a think pair share learning model on the knowledge and attitudes of school-age children in vegetable consumption. The study used pre-experimental research design (one-group pre-post test design). The population in this research is a grade IV student at SDI KHM Noer Surabaya. Sampling with total sampling technique. Respondents in this study numbered 40 respondents. The independent variable in the study was health education with a think pair share learning model. The dependent variables in the study are knowledge and attitude. Data collection using questionnaires. The data was analyzed using the Wilcoxon Sign Rank Test statistical test for knowledge and attitudes with significance 0.05 . The results of the Wilcoxon Sign Rank Test show that health education with a think pair share learning model can affecta child's knowledge $(\mathrm{p}=0.000)$ and attitude $(\mathrm{p}=0.000)$. The results of this study concluded that health education with a think pair share learning model can increase children's knowledge and attitudes in vegetable consumption. Further research is expected to be conducted on the action of vegetable consumption in children with a multivariate statistical approach.

Copyright (C) 2020 Eduhot Journal.All rights reserved.

is Licensed under a Creative Commons AttributionNonCommercial 4.0 International License (CC BY-NC 4.0)

\section{INTRODUCTION}

Vegetables are one of the important foods that must always be consumed at every meal because they are one of the requirements in meeting a balanced nutritional menu [1]. Not only for adults, consuming vegetables is very important to be consumed from the age of children. If the child has a deficiency in consuming vegetables, it will cause the body to lack nutrients such as protein, vitamins, minerals and fiber for the body, the child is also at risk of causing diseases such as the risk of obesity and malnutrition in children.[2]. Groups of school-age children experience a relatively rapid growth process and require relatively large amounts of nutrients so that they need to obtain adequate nutrition[3]. The diet that is applied at the age of children will affect the eating pattern as an adult, so getting children to eat vegetables from an early age is very important[4]. In fact, children are still The Effect of Health Education With Think Pair Share Learning Model on Knowledge and Attitudes of School Age Children in Vegetable Consumption, Sri Puasti Ningsih 
difficult to consume vegetables in adequate quantities. Children consume an average of $70.4 \mathrm{~g} /$ day of vegetables with the lowest vegetable consumption of $15 \mathrm{~g} /$ day and the highest vegetable consumption of $148 \mathrm{~g} /$ day. This prevalence can be bad for children's growth and development. Children can have a great opportunity to suffer from malnutrition because of the food consumed in small amounts[5]. A study by The Gateshead Millennium Baby Study in 2006 in the UK said 20\% of parents reported their children had eating problems, with the highest prevalence of children only wanting to eat certain foods.[6].

According to the Food and Agriculture Organization (FAO) in 2010 only $63.3 \%$ of primary school age children in Indonesia consumed vegetables. The results of the National Socio-Economic Survey (SUSENAS 2014) found that $83.64 \%$ of school-age children in Indonesia consume less vegetables, because children often experience a difficult phase of eating, especially difficult to eat vegetables. Based on the results of the Basic Health Research (Riskesdas) of the Indonesian Ministry of Health in 2013 it was found that an average of $93.5 \%$ of the Indonesian population consumes less fruits and vegetables. Based on initial observations of 4th grade students at Kyai Haji Muhammad Noer Islamic Elementary School / SDI KHM NOER Surabaya, 16 of the 40 students did not like to eat vegetables. As many as $15 \%$, namely 6 students who answered incorrectly when asked to answer several questions about the benefits of consuming vegetables. The students also revealed that every time they ate, they would set aside the vegetables and throw them away. In accordance with the research that has been carried out by Putriana[7]revealed that the consumption of vegetables in school-age children is low, namely around $90 \%$ of school-age children consume vegetables and fruit $<3$ servings/day. A fairly large proportion of children in the world who do not meet the recommendations of the World Health Organization (WHO) in the consumption of vegetables and fruit, which is at least 400 grams / day or as many as 3-5 servings a day. The WHO recommended vegetable requirement is $150-200$ grams equivalent to $1-2$ bowls a day[8]. The reason is because children are picky about their favorite foods, only want to eat certain foods and tend to avoid eating vegetables[9]. The factors that cause vegetable consumption in children are influenced by the characteristics of the child/individual, the characteristics of the parents and the characteristics of the environment. Children prefer junk food, the majority of which do not provide a vegetable menu[10]. Parents have an important role in meeting balanced nutrition in children. Parental support in increasing vegetable consumption in children is one of them by providing and preparing a vegetable menu for lunch and daily meals. Children's knowledge about the importance of vegetables needs to be increased in order to form a habit of consuming vegetables[11]. Research conducted by Bestari states that the cause of low vegetable consumption in children is due to lack of knowledge about nutrition and an attitude of ignoring the importance of eating vegetables, this is triggered because children feel vegetables are food that tastes bad, even though vegetables have a lot of nutritional content in the form of protein and vitamins that are good for growth. child flower. Ineffective nutrition education at the age of children has an impact on lack of knowledge about healthy and balanced food consumption patterns until adulthood, causing wrong behavior and bad consequences for children's growth and development. Children have the potential to suffer from malnutrition because they consume small amounts of vegetables.[12]. In addition, lack of vegetables can also have a negative impact on the visual system, can also cause anemia. Constipation will also be a disease that will be experienced if children consume less vegetables and fruit[13]. Several types of vegetables such as spinach, cassava leaves and kale are known as sources of iron which is important for blood formation. Children with lack of blood (anemia) will feel tired quickly and lack of concentration because the blood is not able to carry oxygen to the brain[14].

According to the results of Nurmahmudah's research, the role of health education is very influential in increasing children's knowledge about vegetables, especially when using learning media to provide a good understanding for children, adapted to the stages of the child's age. The problem is that if children enter school age, children begin to get influence from the outside environment, such as teachers, peers and other people at school, and also the influence of the media, this will have an impact on decreasing the level of preference for vegetable consumption in children.[15]. According to Notoamodjo[16]Increased knowledge is needed to achieve a better degree of health, the higher the level of knowledge a person has, the easier it will be for children to behave in a healthy life. Think

The Effect of Health Education With Think Pair Share Learning Model on Knowledge and Attitudes of School Age Children in Vegetable Consumption, Sri Puasti Ningsih 
pair share (TPS) cooperative learning model is a learning method that aims students are able to think (think), express opinions in pairs (pairs), and share opinions (share) to solve a problem and learn material in the form of collaboration between group members.[17]. This TPS learning model provides opportunities for each student to work independently and collaborate with others. The advantage of this technique is the optimization of student participation[18]. Health education with the TPS method is suitable for school-age children because children will try to think, respond to each other and help in discussions[19]. This TPS is effective in increasing the understanding and activeness of elementary school-aged children in discussions. The weakness of this learning model takes a long time, because students need additional time to understand and change a habit/action[20]. Students find it difficult to understand a concept, so they need a process in concept alignment by the facilitator[21]. However, in this TPS learning model, students are trained to reason and think and are expected to be able to increase knowledge and change children's tendencies (attitudes) to choose vegetable consumption behavior.

\section{METHOD}

This research design uses an experimental research design with pre-experimental research methods with a one-group pre-post test design, where this type of research reveals a causal relationship by involving a group of subjects. The subject group was observed before the intervention, then observed again after the intervention. This study discusses the causal relationship of health education through the think pair share learning model on the knowledge and attitudes of school-age children in vegetable consumption. The targeted population in this study were school-age children (612 years) at SDI KHM Noer Surabaya totaling 235 students, while the affordable population was grade 4 students, totaling 40 students.

The inclusion criteria of this study are:

a. Grade 4 elementary school students who attended and followed the entire research phase.

b. Students who received approval from parents / guardians of students to be respondents in this study.

The exclusion criteria were as follows: Students who did not attend school during the study. The sampling technique in this research is total sampling. The researcher took all the 4 th grade students of SDI KHM Noer, totaling 40 children.

Independent variable (free) is a variable whose value determines another variable. The dependent variable (bound) is a variable whose value is determined by another variable. The independent variable in this study is health education through the think pair share learning model. The dependent variable in this study is the knowledge and attitudes of school-age children in vegetable consumption.

The instrument in this study used a structured questionnaire. Knowledge and attitude using ordinal data. Knowledge is divided into three categories, namely good, sufficient and lacking. Attitudes are divided into 2 categories, namely positive attitudes and negative attitudes. The knowledge questionnaire consists of 20 questions, namely kinds of vegetables (questions no. 1,3 ), the benefits of eating vegetables (questions no. 14,15,18), vegetable content (questions no. 4,5,6,7,8, 10,20 ), the proper way of processing vegetables (questions no.2,9,12,13), frequency and amount of intake of eating vegetables (questions no.11), the impact of not eating vegetables (questions no.16,17,19) . The score for the knowledge questionnaire is a score of 1 for the correct answer and a score of 0 for the wrong answer. The knowledge questionnaire contains 20 questions with true $=1$, false $=0$, the maximum score is 20 .

Researchers carried out the data collection process after obtaining permission from the Head of SDI KHM Noer Surabaya, by previously getting a cover letter from the Dean of the Faculty of Nursing, Universitas Airlangga for initial data collection. The first step after obtaining approval from the school, the researchers conducted a survey of initial data regarding the knowledge and attitudes of children in vegetable consumption through observations and interviews with grade 4 students. Researchers took all samples of grade 4 students with a total sampling approach of 40 students. The researcher chose the 4th graders of elementary school because the 4th graders had received material about healthy and nutritious food and was recommended by the principal. The researcher applied for 
informed consent to the respondent's parents so that the respondent was willing to become the research subject. The statement letter is given to the child before the research is carried out and then given to the parent/guardian of each student. The statement letter has been equipped with a research explanation sheet so that parents understand what will be given to their children. The statement letter which was signed by the parents was collected back to the researcher. After obtaining informed consent from parents, the researcher explained the purpose of the study and conducted an initial assessment of the students using a pre-test questionnaire instrument. Questionnaire sheets were filled out by students containing demographic data, level of knowledge and attitudes. The results of the pretest carried out,

Descriptive analysis, analyzing data using distribution tables and confirmed in the form of percentages and narratives. The data that has been collected is tabulated, data analysis is carried out using the Wilcoxon Signed Rank Test statistical test to determine the comparative correlation of two samples on ordinal data in each dependent variable. If it is set $=0.05$ and a $p$ value of 0.05 is obtained, then $\mathrm{H} 1$ is accepted, namely there is a change in the level of knowledge and attitudes of children after being given health education with the think pair share learning model.

\section{RESULTS AND DISCUSSION}

\subsection{RESULT}

The demographic data of these respondents describes the characteristics of the respondents including: the order of children in the family, gender, age of the child, information about the importance of consuming vegetables, sources of information and respondents' experiences in receiving health education. The sample used in this study were 4th grade students at SDI KHM Noer as many as 40 students. Students who qualify as the research sample are 40 students. Determination of respondents is done by purposive sampling technique. Characteristics of respondents can be seen in table 1:

\begin{tabular}{|c|c|c|c|}
\hline No & Characteristics of respondents & $\mathbf{n}$ & $\%$ \\
\hline \multirow[t]{4}{*}{1} & Age & & \\
\hline & 10 & 14 & $35 \%$ \\
\hline & 11 & 26 & $65 \%$ \\
\hline & Total & 40 & $100 \%$ \\
\hline \multirow[t]{4}{*}{2} & Gender & & \\
\hline & Man & 21 & $52.5 \%$ \\
\hline & Woman & 19 & $47.5 \%$ \\
\hline & Total & 40 & $100 \%$ \\
\hline \multirow[t]{7}{*}{3} & Order of children in the family & & \\
\hline & 1 & 14 & $35 \%$ \\
\hline & 2 & 10 & $25 \%$ \\
\hline & 3 & 6 & $15 \%$ \\
\hline & 4 & 4 & $10 \%$ \\
\hline & 5 & 6 & $15 \%$ \\
\hline & Total & 40 & $100 \%$ \\
\hline \multirow[t]{9}{*}{4} & $\begin{array}{l}\text { Experience getting information on the importance of } \\
\text { consuming vegetables }\end{array}$ & & \\
\hline & Once & 31 & $77.5 \%$ \\
\hline & Never & 9 & $22.5 \%$ \\
\hline & Total & 40 & $100 \%$ \\
\hline & Source of information & 20 & $40 \%$ \\
\hline & Parent & 23 & $46 \%$ \\
\hline & School teachers & 7 & $14 \%$ \\
\hline & Media (television, radio, newspapers) & 50 & $100 \%$ \\
\hline & Total & & \\
\hline 5 & get health education & & \\
\hline
\end{tabular}




\begin{tabular}{lrc} 
Once & 16 & $40 \%$ \\
Never & 24 & $60 \%$ \\
\hline Total & 40 & $100 \%$
\end{tabular}

The demographic data of the respondents referred to in table 1 shows that most of the respondents are 11 years old and a few are 10 years old. Most of the respondents were male, namely 21 children and the number of female respondents was 19 children. Most of the respondents are the first child and a few are the 4th child. The majority of respondents have received information about the importance of consuming vegetables. There are also some respondents who never received information about the importance of consuming vegetables. Most of the respondents received information about the importance of vegetable consumption through school teachers, while a small number of respondents received information about the importance of vegetable consumption through the media (TV, radio, newspapers). Based on table 1, it shows that most of the respondents had never previously received health education or counseling about the importance of consuming vegetables, while a small proportion of respondents had received health education or counseling about the importance of vegetable consumption. This section presents the results of research showing the effect of health education with the think pair share learning model on children's knowledge and attitudes in vegetable consumption at SDI KHM Noer Surabaya. Knowledge of vegetable consumption before and after being given health education with the think pair share learning model. This section presents the results of research showing the effect of health education with the think pair share learning model on children's knowledge and attitudes in vegetable consumption at SDI KHM Noer Surabaya. Knowledge of vegetable consumption before and after being given health education with the think pair share learning model. This section presents the results of research showing the effect of health education with the think pair share learning model on children's knowledge and attitudes in vegetable consumption at SDI KHM Noer Surabaya. Knowledge of vegetable consumption before and after being given health education with the think pair share learning model.

Table.2 Knowledge of vegetable consumption before and after being given health education with the think pair learning model shared at SDI KHM Noer Surabaya

\begin{tabular}{lcccc}
\multicolumn{1}{c}{ Category } & \multicolumn{2}{c}{ Before } & \multicolumn{2}{c}{ After } \\
\hline Well & $\mathbf{n}$ & $\mathbf{\%}$ & $\mathbf{n}$ & $\mathbf{\%}$ \\
Enough & 1 & $2.5 \%$ & 33 & $82.5 \%$ \\
Not enough & 17 & $42.5 \%$ & 7 & $17.5 \%$ \\
\hline Total & 22 & $55 \%$ & 0 & $0 \%$ \\
\hline
\end{tabular}

Based on the table. 2 shows that the majority of respondents have increased knowledge after being given a health education intervention on the importance of vegetable consumption with the think pair share learning model. Most of the respondents were in good category after the intervention. Knowledge increased to 33 respondents with good knowledge and 7 respondents with moderate knowledge. The results of the Wilcoxon sign rank test statistic with the value of sig (2-tailed) showed that there was a difference in the level of knowledge before and after with a significance value of $p=$ 0.000 , namely p 0.05 . H1 is accepted, namely that there is an effect of health education with the think pair share learning model on the knowledge of school-age children in vegetable consumption. $\mathrm{m}$ Attitudes about vegetable consumption before and after being given health education with the think pair share learning model.

Table.3 Attitudes about vegetable consumption before and after being given health education with the think pair share learning model at SDI KHM Noer Surabaya in June 2017

\begin{tabular}{lcccc}
\multicolumn{1}{c}{ Category } & \multicolumn{2}{c}{ Before } & \multicolumn{2}{c}{ After } \\
\hline & $\mathbf{n}$ & $\mathbf{\%}$ & $\mathbf{n}$ & $\mathbf{\%}$ \\
Positive & 20 & $50 \%$ & 24 & $60 \%$ \\
Negative & 20 & $50 \%$ & 16 & $40 \%$ \\
\hline Total & 40 & $100 \%$ & 40 & $100 \%$
\end{tabular}

Based on the table. 3 shows that before being given health education on the importance of 
vegetable consumption with the think pair share learning model, respondents had the same attitude with 20 respondents positive attitudes and 20 respondents negative attitudes. The majority of respondents showed an increase in attitude. Respondents after being given the intervention were 24 respondents who had a positive attitude, while those who had a negative attitude were 16 respondents. The results of the Wilcoxon sign rank test statistic for the sig (2-tailed) value showed that there was a difference in attitude results before and after the significance value of $p=0.000$, namely $p 0.05$. H1 is accepted, namely that there is an effect of health education with the think pair share learning model on the attitudes of school-age children in vegetable consumption.

\subsection{DISCUSSION}

The school should play an active role in the implementation of education with the think pair share learning model in increasing correct and healthy vegetable consumption behavior for students. The school with the help of the local puskesmas staff should monitor the nutritional status of students and provide health education related to nutrition on a regular basis. The think pair share method is an alternative educational method that can be applied in the scope of school education and nursing science to teach the importance of consuming vegetables for children. Further research is expected to conduct research on the act of consuming vegetables in children with a multivariate statistical test approach so that the test results can control the results more deeply.

\section{CONCLUSION}

Based on the results of research that has been carried out at SDI KHM Noer Surabaya, Sidotopo Wetan Village, Kenjeran District, Surabaya City, it is concluded:

Health education with the think pair share learning model can increase the knowledge of school-age children on vegetable consumption at SDI KHM NOER Surabaya. After being given health education with the think pair share learning model, the majority of respondents have increased knowledge in the good category. Health education with think pair share learning model can change the attitude of school-age children into a positive attitude towards vegetable consumption at SDI KHM NOER Surabaya. In this study, data shows that good knowledge is not necessarily accompanied by a positive attitude. This can happen because of other factors that influence attitudes such as individual experiences, the influence of others and emotional factors. Health education with the think pair share learning model can increase the knowledge of children at SDI KHM NOER Surabaya in vegetable consumption behavior because the TPS learning model invites students to play an active role in solving a problem and think critically so that children are able to remember the material given. Health education with the think pair share learning model can improve the attitudes of children at SDI KHM Noer Surabaya in vegetable consumption behavior because the TPS learning model requires children to respect other people's opinions and respect others who are expressing opinions. Respecting others will bring out a positive attitude from each child.

\section{REFERENCES}

[1] H. Hermiyanty, S. I. Fitrasyah, U. Aiman, and M. R. Ashari, "Gambaran Pengetahuan dan Praktik Menyusun Menu Sarapan pada Orang Tua Siswa SDIT Al-Fahmi Palu," Ghidza J. Gizi dan Kesehat., vol. 2, no. 1, 2020, doi: 10.22487/ghidza.v2i1.3.

[2] P. A. Arza, Y. Masnarivan, R. K. Dewi, F. Fitriyani, D. F. Rahmah, and A. K. Ananda, "EDUKASI GIZI SEIMBANG DAN MAKANAN JAJANAN SEHAT DI SDN 39 PASAR AMBACANG KOTA PADANG," Bul. Ilm. NAGARI MEMBANGUN, vol. 3, no. 1, 2020, doi: 10.25077/bina.v3i1.166.

[3] S. Mawani and S. S. Ndari, "Menu Gizi Seimbang Sebagai Pencegahan Stunting Anak Usia Di PDR 4 Kelurahan Cilandak Barat Jakarta Selatan," Pros. Abdimasmu, 2019.

[4] H. Dasman, "Empat dampak stunting bagi anak dan negara Indonesia," Conversat. (Disipln Ilmiah, gaya Jurnalistik), 2019.

[5] A. Usman and S. Mega Buana Palopo, "Hubungan Sosial Ekonomi Dan Asupan Gizi Ibu Dengan Kejadian Kekurangan Energi Kronik Pada Ibu Hamil," JIKI J. Ilm. Kesehat. IQRA, vol. 7, no. $02,2019$.

The Effect of Health Education With Think Pair Share Learning Model on Knowledge and Attitudes of School Age Children in Vegetable Consumption, Sri Puasti Ningsih 
[6] I. Indanah and Y. Yulisetyaningrum, "PERKEMBANGAN SOSIAL EMOSIONAL ANAK USIA PRA SEKOLAH," J. Ilmu Keperawatan dan Kebidanan, vol. 10, no. 1, 2019, doi: 10.26751/jikk.v10i1.645.

[7] E. Gustina, F. Abdussalam, and W. Saputra, "PENINGKATAN PERILAKU SEHAT PADA SISWA SEKOLAH DASAR MELALUI PHBS DI DESA GONDANGLEGI DAN PUCANGAN, KECAMATAN AMBAL, KABUPATEN KEBUMEN," J. Pemberdaya. Publ. Has. Pengabdi. Kpd. Masy., vol. 2, no. 1, 2019, doi: 10.12928/jp.v2i1.470.

[8] T. Damayanti, E. A. Murbawani, and D. Y. Fitranti, "HUBUNGAN USIA PENGENALAN SAYUR DAN BUAH DENGAN TINGKAT KONSUMSI SAYUR DAN BUAH PADA ANAK PRASEKOLAH USIA 3-5 TAHUN," J. Nutr. Coll., vol. 7, no. 1, 2018, doi: 10.14710/jnc.v7i1.20770.

[9] E. S. D. Damanik, "Hubungan pola asuh orang tua dengan kesulitan makan pada anak usia 3-5 tahun di desa Sukaraya Kecamatan Pancur Batu tahun 2018," Skripsi, 2018.

[10] V. Silawati and N. Nurpadilah, "Pengaruh Pemberian Makanan Tambahan Dan Susu Terhadap Penambahan Berat Badan Pada Ibu Hamil KE (Kekurangan Energi Kronis) di Wilayah Kerja Puskesmas Curug Kabupaten Tangerang Tahun 2018," J. Heal. Sci. Physiother., vol. 1, no. 2, 2019, doi: 10.35893/jhsp.v1i2.16.

[11] H. Daming, H. K. Hengky, and F. Umar, "Faktor-Faktor yang Mempengaruhi Kejadian Stunting pada Balita di Puskesmas Salo Kabupaten Pinrang," J. Ilm. Mns. dan Kesehat., vol. 2, no. $1,2019$.

[12] D. Pranungsari, I. C. Anwar, S. Maarifudin, and V. Arisandi, "EDUKASI KESEHATAN KONSUMSI SAYUR DAN BUAH, SERTA PENGELOLAAN SAMPAH PADA ANAKANAK SD NEGERI KeMPONG," J. Pemberdaya. Publ. Has. Pengabdi. Kpd. Masy., vol. 3, no. 2, 2019, doi: 10.12928/jp.v3i2.766.

[13] J. I. D. Sulistiono and E. Malinti, "Frekuensi Asupan Makan Sumber Serat Dan Kejadian Konstipasi Pada Lansia Advent Dan Non-Advent," Klabat J. Nurs., vol. 1, no. 2, 2019, doi: 10.37771/kjn.v1i2.410.

[14] U. Laili and F. Nisa', "Pencegahan Konstipasi pada Ibu Nifas dengan Early Exercise," J. Bidan Cerdas, vol. 2, no. 2, 2019, doi: 10.33860/jbc.v2i2.178.

[15] C. N. Irma, K. Nisa, and S. K. Sururiyah, "Keterlibatan Orang Tua dalam Pendidikan Anak Usia Dini di TK Masyithoh 1 Purworejo," J. Obs. J. Pendidik. Anak Usia Dini, vol. 3, no. 1, 2019, doi: 10.31004/obsesi.v3i1.152.

[16] T. M. Hasanah, Y. A. Majid, and S. Tirtayanti, "Kartu Bergambar Meningkatkan Pengetahuan, Sikap, dan Prosedur Mencuci Tangan Anak Kelas 5 Sekolah Dasar Di SD Muhammadiyah 14 Balayudha Palembang Tahun 2019," Healthc. Nurs. J., vol. 2, no. 1, 2019, doi: 10.35568/healthcare.v2i1.485.

[17] hilmi R. F. N. Hanifah and R. Nuraeni, "Perbedaan Peningkatan Kemampuan Pemecahan Masalah Matematis Siswa antara Think Pair Share dan Think Talk Write," Mosharafa J. Pendidik. Mat., vol. 9, no. 1, 2020.

[18] A. H. Nuryanto, "Pengaruh Strategi Think Pair Share pada Pembelajaran Guided Inquiry terhadap Kemampuan Berpikir Kritis,” J. Ris. Pendidik. Fis., vol. 5, no. 2, 2020.

[19] S. S. Latifah and I. P. Luritawaty, "Think Pair Share sebagai Model Pembelajaran Kooperatif untuk Peningkatan Kemampuan Pemecahan Masalah Matematis," Mosharafa J. Pendidik. Mat., vol. 9, no. 1, 2020.

[20] D. Apriyanti and M. Ayu, "THINK-PAIR-SHARE: ENGAGING STUDENTS IN SPEAKING ACTIVITIES IN CLASSROOM," J. English Lang. Teach. Learn., vol. 1, no. 1, 2020, doi: 10.33365/jeltl.v1i1.246.

[21] I. Rosdi, "Meningkatkan Minat dan Hasil Belajar Siswa Pada Mata Pelajaran Ekonomi Melalui Pembelajaran Kooperatif Tipe TPS (Think Pair Share)," Indones. J. Soc. Sci. Educ., vol. 2, no. 2, 2020.

The Effect of Health Education With Think Pair Share Learning Model on Knowledge and Attitudes of School Age Children in Vegetable Consumption, Sri Puasti Ningsih 